\title{
Journal of Mammalian Evolution
}

The Journal of Mammalian Evolution would like to thank Eric Sargis (Peabody Museum, Yale University) for his years of dedication. Eric first joined the Editorial Board in 2002 and became the first Book Review Editor in 2004. He also served as Treasurer of the Society for the Study of Mammalian Evolution from 2002 through 2007. Eric is stepping down as Book Review Editor, although some of the 100 reviews he handled will continue to be published in the current volume. Eric will now serve the journal as Associate Editor. The journal welcomes the new Book Review Editor, Tim Gaudin (University of Tennesee at Chattanooga), who has been on the Editorial Board since 2007. We offer Eric and Tim thanks and best wishes in their new responsibilities.

Please refer to the journal masthead for the complete list of current editors and editorial board members, along with their contact information. The following are stepping down from the board and are thanked for their service: Emmanual J. P. Douzery (Université Montpellier II), Norhiro Okada (Tokyo Institute of Technology), Link Olson (University of Alaska Museum), Nancy B. Simmons (American Museum of Natural History), Michael J. Stanhope (Cornell University), Emma C. Teeling (University College Dublin), and Robert S. Voss (American Museum of Natural History). The journal welcomes the following new board members: Robin M.D. Beck (American Museum of Natural History), Jonathan I. Bloch (Florida Museum of Natural History), Darin A. Croft (Case Western Reserve University), Jonathan H. Geisler (New York College of Osteopathic Medicine), and Norberto P. Giannini (Universidad de Tucumán). 